Article

\title{
Exploring the Effects of a Modified Higher Education Performance Service Quality Model on Organisational Sustainability: The Case of Malaysian Polytechnics
}

\author{
Sulaiman Mohammed Khalid ${ }^{1}$ (D), Khairul Anuar Mohd Ali ${ }^{2, *}$, Zafir Khan Mohamed Makhbul ${ }^{2,3}$, \\ Mohd Helmi Ali ${ }^{2,3}$ and Siti Daleela Mohd Wahid ${ }^{4}$
}

Citation: Khalid, S.M.; Ali, K.A.M.; Makhbul, Z.K.M.; Ali, M.H.; Wahid, S.D.M. Exploring the Effects of a Modified Higher Education Performance Service Quality Model on Organisational Sustainability: The Case of Malaysian Polytechnics. Sustainability 2021, 13, 8105. https:// doi.org/10.3390/su13148105

Academic Editor:

Evangelos Grigoroudis

Received: 24 May 2021

Accepted: 9 July 2021

Published: 20 July 2021

Publisher's Note: MDPI stays neutral with regard to jurisdictional claims in published maps and institutional affiliations.

Copyright: (c) 2021 by the authors. Licensee MDPI, Basel, Switzerland. This article is an open access article distributed under the terms and conditions of the Creative Commons Attribution (CC BY) license (https:// creativecommons.org/licenses/by/ $4.0 /)$
1 Department of Tourism and Hospitality, Politeknik Muadzam Shah, Muadzam Shah 26700, Pahang, Malaysia sulaiman@pms.edu.my

2 Graduate School of Business, Universiti Kebangsaan Malaysia, Bangi 43600, Selangor, Malaysia; zafir@ukm.edu.my (Z.K.M.M.); mohdhelmiali@ukm.edu.my (M.H.A.)

3 Faculty of Economics and Management, Universiti Kebangsaan Malaysia, Bangi 43600, Selangor, Malaysia

4 Faculty of Business and Management, Universiti Teknologi MARA, Cawangan Melaka, Alor Gajah 78000, Melaka, Malaysia; sitid365@uitm.edu.my

* Correspondence: kabma@ukm.edu.my

\begin{abstract}
Higher education service quality and performance in technical and vocational education and training (TVET) is critical for developing human capital for economic survival; however, the effects of service quality on organisational performance are still unclear. Furthermore, neglecting employee soft factors and ignoring higher education-specific models have hindered efforts to develop a comprehensive model for service quality excellence in order to improve higher education performance for organisations. This study aims to assess higher education service quality based on a modified higher education performance (modified HEdPERF) model, as well as consideration of the mediating effects of soft factors (i.e., job satisfaction and organisational commitment) in Malaysian polytechnic institutions. Based on random sampling, 214 department heads from 33 polytechnic institutes in Malaysia participated in this study. Data were collected through self-administered questionnaires and were analysed using AMOS. The results uncover that service quality significantly affects job satisfaction, thus positively affecting organisational commitment, which enhances organisational performance sustainability. The findings also reveal that job satisfaction fully mediates the relationship between service quality and organisational commitment. Similarly, organisational commitment fully mediates the relationship between job satisfaction and organisational performance sustainability. The results have important implications for enhancing organisational performance sustainability in a TVET context when implementing the modified HEdPERF service quality model with simultaneous attention paid towards employee soft factors.
\end{abstract}

Keywords: service quality; soft factors; modified HEdPERF; job satisfaction; organisational commitment; organisational performance sustainability

\section{Introduction}

The Sustainable Development Goals (SDGs) 2016-2030 defined by the United Nations Educational, Scientific, and Cultural Organization (UNESCO) identified technical and vocational education and training (TVET) as a strategy for the development of sustainable societies and economies. The main strategies under the TVET agenda promote social mobility through access and equity, lifelong learning, and eradicating unemployment for sustainable development. Alongside the rapid technological changes due to the Fourth Industrial Revolution (IR4.0), workers often lose their employment due to job redundancy and irrelevance, leading to a demand for TVET in order to support learning new skills and other necessary work-related education [1]. Several studies have proposed that the neglect of TVET will hamper sustainable development [1,2]. 
TVET gained more attention in Malaysia when the Malaysian government recognised it as an enabler for economic development and as a suitable strategy for increasing social mobility in line with global TVET aims [1]. With the increasing demand from various industries for TVET for graduates, TVET institutions must continuously deliver quality education and training through providing excellent service quality [2], since such practice can drive high graduate employability (GE) and promote organisational performance [1]. Given that the current high GE rates in TVET institutions can only be consistently attained through sustaining employee service quality, employees are always at the centre of superior service quality and performance sustainability [3].

Many previous studies have shown a lack of understanding regarding the comprehensive structure of service quality in the context of performance sustainability $[4,5]$. Past studies on service quality have primarily focused on the definition and components of service quality, and others have only used direct relationships to explore consequences [3]. Despite the rising recognition of employee soft factors in the workplace and their influence on employee output and effectiveness [6,7], there is limited research on the roles of employee soft factors in the process by which organisation service quality can affect employee performance (herein referred to as gap 1).

In addition, direct relationship assessment for measuring performance has produced inconsistent results [8,9]. The accurate and critical path from service quality to performance is also still vague $[4,10]$. Moreover, previous studies have also made improper choices regarding service quality measurement models using generic scales (SERVQUAL and SERVPERF) in higher education settings, which tend to produce general recommendations due to the lack of context-specific features [11,12]. It is not clear from the existing literature whether the outcomes are the same when employing generic and specific models in highcontact service settings like those considered in this study (herein referred to as gap 2).

This paper addresses both of these research gaps by using two approaches, namely, the use of soft factors as mediators and a modified HEdPERF model as a predictor for developing an integrative research model. This work proposes that internal service quality can have a critical role in generating an appropriate atmosphere for encouraging organisational behaviours by expecting and fulfilling the wants and needs of all the employees in the organisation, which would lead to greater employee satisfaction, commitment, and well-being [13], thus promoting performance sustainability. Furthermore, employee soft factors can also mediate the relationship between quality and performance $[14,15]$. This research model was applied in a Malaysian TVET context to test the effects of soft factors in the relationship between service quality and organisational performance when using a modified HEdPERF model.

\section{Literature Review}

\subsection{Theoretical Background}

The research framework employed in this study was based on the four stages of systems theory in order to enable the analysis of an entire organisation. The variables involved stem from operations management, organisational behaviour/psychology, and management accounting disciplines, with importance given to the Malaysian polytechnic system in the TVET sector for higher education. Systems theory is the most important approach for predicting performance sustainability $[16,17]$. Studies agree that the theory of quality in higher education should resolve the relationship between the input, process, output, and long-term results [18,19]. As a result, several scholars have adopted systems theory to analyse organisational performance sustainability as a whole [20,21].

A systems theory approach for Malaysian polytechnic institutes comprises service quality dimensions, namely, academic aspects, non-academic aspects, programme issues, access, and physical facilities, which are collectively referred to as the input stage. Soft factors (job satisfaction and organisational commitment) refer to the process stage and the output stage indicates organisational performance sustainability. Finally, feedback can be positive, negative, or balanced. Feedback is important for polytechnic system flexibility 
and openness to the environment. In this study, systems theory helps to provide a holistic view of the polytechnic institutes in the context of the improvement of higher education system sustainability, providing a comprehensive and analytical view for explaining why or how phenomena occur in the whole supply chain of higher education institutions. These four main stages consider organisation interconnection, synergies, and interdependence in the context of maintaining sustainability and performance.

In summary, systems theory is the main concept with which service quality and organisational performance sustainability is considered in this paper. This paper provides a meaningful understanding of the effects of soft factors on associations in terms of the links between service quality and organisational performance sustainability in a polytechnic institute context.

\subsection{Service Quality}

SERVQUAL, proposed by [22], uses five factors to measure the service quality that is widely accepted in service settings, including higher education; however, there is much debate regarding the validity and reliability of the model to measure high-contact service settings such as higher education [23]. Furthermore, the current developments in higher education service quality management studies suggest using an industry-specific measurement model to investigate service quality in higher education [23] to obtain more understanding and meaningful findings.

HEdPERF (Higher Education Performance), proposed by [24], is a more complete measurement model [25] to assess the service quality in the higher education sector that uses five critical elements, namely, non-academic aspects, academic aspects, programme issue, reputation, and access [25]. The recently published results on organisational quality management revealed that the ability of higher education organisations to implement HEdPERF accordingly in the course of daily work activities can increase customers' satisfaction with organisational sustainability [23]. HEdPERF has been empirically tested for unidimensionality, reliability and validity using both exploratory and confirmatory factor analysis and was found to be a better model than SERVQUAL and SERVPERF [26]. The HEdPERF scale is more comprehensive and can capture the authentic determinants of service quality within the higher education sector [27], and the findings demonstrate the apparent superiority of the factors of the HEdPERF scale. HEdPERF encompasses all the aspects of the total service environment [26] in education settings. This element has been used as an important indicator for measuring the achievement of service quality in educational organisations.

However, the current model has been modified in line with the recommendations of [25]. Physical facilities were integrated into the present study due to the critical nature of the research context. The integration of physical facilities is consistent with the assertion made by [22] that service firms must pay attention to the physical environment to meet internal customer needs. The physical facility is a core component as a vast amount of the extant literature claims this variable to be among the critically important factors in service organisations [22,28] for internal customers to carry out daily operational tasks.

Numerous recent studies have used HEdPERF to investigate service quality in higher education; one such study included a cohort of 187 lecturers from Malaysian polytechnics and assessed the model's suitability for measuring the sustainability performance of higher education settings [3]. They also proved that the implantation of the HEdPERF model was able to predict employee job satisfaction. The components of the HEdPERF model are suited to the higher education context specifically and help employees carry out their daily roles and responsibilities. Another study investigated service quality among 241 international students at three public Malaysian university campuses in Kuala Lumpur [27]. Their findings showed that all HEdPERF dimensions influenced student satisfaction, institutional image and student loyalty. Additionally, it was found in another study that the HEdPERF model can enable higher education managers to identify aspects through which students 
gauge the quality of the service [28], and another found that the HEdPERF model positively impacted the behavioural intentions among higher education customers in India [29].

\subsection{Job Satisfaction and Organisational Commitment}

Quality elements can be divided into soft factors or human aspects and hard factors or technical elements [30]. The former refers to management tools, techniques and practices, while the latter is associated with management concepts and principles. For example, soft factors include corporate image, job satisfaction, and commitment, whereas hard factors include tools, procedure and benchmarking.

Job satisfaction is a source of competitiveness and leads to firm sustainability in many sectors, including higher education. Job satisfaction will lead to good outcomes if the internal and external customers are satisfied. A satisfied internal customer will be an efficient and effective service provider. This, in turn, will satisfy the external customer (i.e., students) [31,32]. Therefore, job satisfaction must be emphasised and the organisation must strive to achieve higher satisfaction levels among internal customers to deliver high-quality performance sustainability levels.

On the other hand, organisational commitment has important consequences for employees, such as increased employee morale, reduced stress, and improved productivity. Through service quality implementation, employees receive opportunities to be involved in setting goals, measures or rules to encourage their commitment. Thus, they can highlight their constraints and requirements with regard to the performance of a given task. Subsequently, employees are provided with favourable work designs and their job clarity is thereby enhanced [33]. In this context, it has been claimed that employee involvement significantly impacts employees' obligation towards their jobs and their organisations [34]. Additionally, it has been argued that when employees become emotionally committed, they will work harder to attain the organisation's goals and targets and be more loyal to their organisation [35-37].

\section{Conceptual Framework and Hypotheses Development}

The conceptual framework (Figure 1) was developed to investigate the effect of service quality on organisational performance sustainability when the mediating effect of job satisfaction and organisational commitment involved in the relationship.

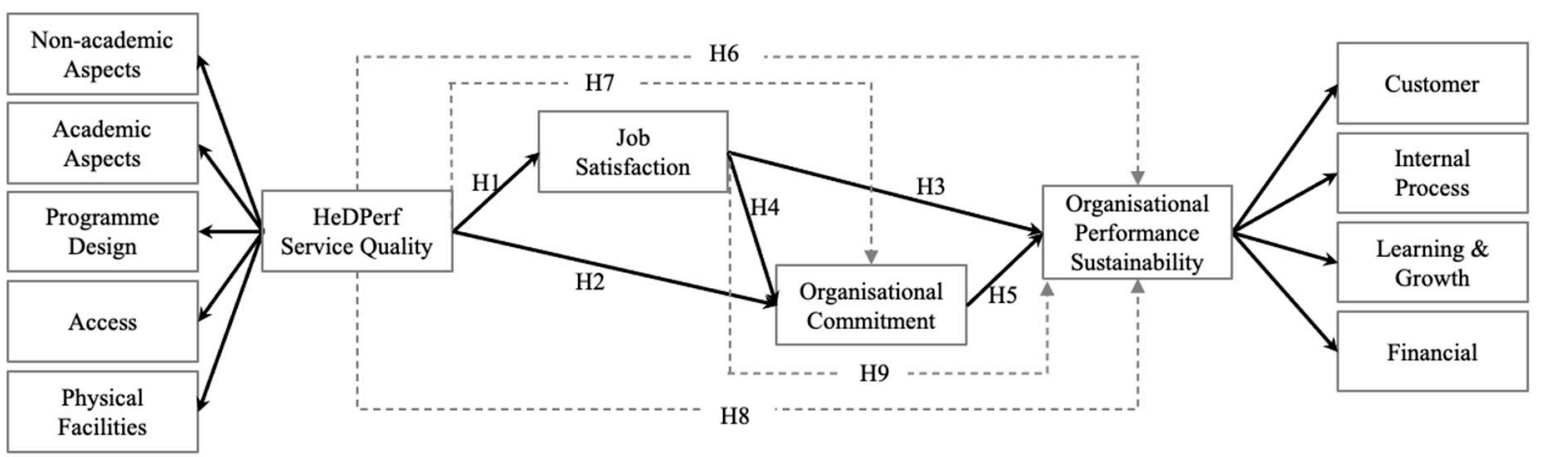

Figure 1. Proposed conceptual framework. Notes: dashed line indicates indirect relationship; (H6: HEdPERF Service Quality $\rightarrow$ Job Satisfaction $\rightarrow$ Organisational Performance Sustainability; H7: HEdPERF Service Quality $\rightarrow$ Job Satisfaction $\rightarrow$ Organisational Commitment; H8: HEdPERF Service Quality $\rightarrow$ Organisational Commitment $\rightarrow$ Organisational Performance Sustainability; H9: Job Satisfaction $\rightarrow$ Organisational Commitment $\rightarrow$ Organisational Performance Sustainability).

\subsection{Service Quality Affects Job Satisfaction}

Many studies have investigated the relationship between service quality and satisfaction $[37,38]$. Hence, as explained in the service quality management literature, service quality aims to help an organisation regularly achieve customer satisfaction [39]. The focus of customers (internal customers-employees) reflects the organisation's efforts to meet or 
exceed their needs and, consequently, generate satisfaction [26,38]. By implementing a quality strategy, employees receive opportunities to be involved in goal setting and measures or rules to improve their commitment. Thus, they can highlight their constraints and requirements with regard to the performance of a task. Subsequently, employees are provided with favourable work designs and their job clarity is thereby enhanced [33]. In this regard, it has been claimed that employee involvement significantly impacts employees' obligation towards their jobs and their organisations [34], leading to high levels of satisfaction and participation in their work and commitment and loyalty to their organisation [33]. Service quality ensures that firms can adapt to dynamic customer requirements more quickly and maintain business sustainability. In the same way, it has been found that service quality can affect customer satisfaction [40]. Even though studies generally survey external customer satisfaction, it has been established that external customer satisfaction is the result of the satisfaction of internal customers [31,32]. Another study identified the relationship between service quality and job satisfaction among employees in a higher education setting based on a survey of 134 faculty members and administrators [37]. Therefore, the current study presents the following hypothesis:

Hypothesis 1 (H1). Service quality has a significant effect on job satisfaction.

\subsection{Service Quality Affects Organisational Commitment}

Organisations require committed employees so that they can best serve external customers [33] and avoid customer switching [41]. A recent study in China using a multilevel method found that organisations could achieve their targets and objectives by ensuring internal service quality that enhanced an employee's commitment to work due to improved retention [42]. Committed employees rarely decide to leave organisations or change jobs. A committed employee is more likely to produce high-quality work, come to work on time, keep their job, and be loyal to an organisation. Additionally, numerous studies have shown that ensuring service quality enhances the commitment throughout an organisation [42,43], as shown in a study that surveyed 275 respondents in China, proving that internal marketing could curb key workers from quitting [42]. Therefore, the current study presents a second hypothesis, as follows:

Hypothesis 2 (H2). Service quality has a significant effect on organisational commitment.

\subsection{Job Satisfaction Affects Organisational Performance Sustainability}

Numerous organisations that adopted service quality management have experienced an improvement in satisfaction and also in organisational performance sustainability [44-46] due to service quality being able to produce an environment that is constructive for the internal customers (employees) and external customers (final product recipients) of an organisation. It has been delineated that a satisfied internal customer (employee) always serves as a precondition to external customers' satisfaction [31,32]. A satisfied internal customer behaves positively (productively, creatively, and responsively), driving organisational productivity, delivering value to the external customer and achieving a strong performance towards sustainability [31,32]. A satisfied internal customer is a happy person with positive behaviour that can effectively and efficiently deliver results to the organisation. An organisation that retains more satisfied internal customers will be more successful, more profitable and able to achieve organisational performance sustainability.

On the other hand, a dissatisfied internal customer may become an enemy to the organisation by spreading negative information about the organisation, affecting other employees by damaging the firm's image and consequently demolishing the organisational performance sustainability. Dissatisfied internal customers tend to show deviant workplace behaviour, which, in turn, decreases performance [47]. Many other negative consequences are related to dissatisfied internal customers, such as disloyalty, increased accidents, turnover, and absenteeism $[47,48]$. In brief, employee satisfaction is critical and 
cannot be ignored in any organisation, as employees are the main drivers of an organisation's performance sustainability. A study in the banking sector, assessing the link between satisfaction and financial performance from 2004 to 2014, revealed a significant relationship at the country level [49]. Satisfaction was critical in explaining banks' financial performance via the effects of improving service quality. Another comprehensive study examined the service-profit chain via 85 executives, 380 employees and 289 customers in India [33]. The method and structural equation modelling (SEM) techniques employed for data analysis found a positive and significant relationship between internal customer satisfaction and the implementation of internal service quality, which improves performance. A link between satisfaction and performance has also been uncovered [50]. Regarding the numerous previous studies finding links between satisfaction and performance, some studies have found that satisfaction was unable to increase organisational performance [51]. Therefore, these mixed results require new analyses and the current study presents a third hypothesis, as follows:

Hypothesis 3 (H3). Job satisfaction has a significant effect on organisational performance sustainability.

\subsection{Job Satisfaction Affects Organisational Commitment}

The leading view in the literature examining the connection between job satisfaction and organisational commitment concurs that there is a positive link between the two concepts [25]. Job satisfaction is related to high commitment and performance and is negatively related to turnover. Satisfied employees exert greater effort and have higher productivity due to enjoying their work; there is less absenteeism and employees embrace an organisation's values and objectives. Numerous previous studies show that job satisfaction can influence organisational commitment: a study conducted in non-Western countries found that employees who are satisfied with their job remain at their organisation because they want to [52]. The association between job satisfaction and organisational commitment was studied among 872 nurses and medical administrators in three hospitals in Turkey [53]. It was found that there was a significant and positive relationship between job satisfaction and organisational commitment. Although many studies concur that job satisfaction influences organisational commitment, some studies have presented mixed findings [54,55]. Therefore, the current study presents a fourth hypothesis, as follows:

Hypothesis $4 \mathbf{( H 4 ) . ~ T h e r e ~ i s ~ a ~ p o s i t i v e ~ r e l a t i o n s h i p ~ b e t w e e n ~ j o b ~ s a t i s f a c t i o n ~ a n d ~ o r g a n i s a t i o n a l ~}$ commitment.

\subsection{Organisational Commitment Affects Organisational Performance Sustainability}

Commitment involves organisation-wide commitment, rather than commitment that is confined to a certain department or individual. It involves a range of people from top management to working-level divisions, where internal customers perform their functions [56]. One study revealed that committed employees contribute to organisational achievement [43]. A study using resource theory among 403 sales representatives and their supervisors in East and Central Africa found that commitment improved performance [57]. A study among 250 employees and 25 supervisors in manufacturing companies in China discovered that commitment has a direct influence on performance [13]. A number of previous studies $[33,39]$ determined that organisational commitment leads to outcomes that benefit the organisation, such as employees working harder towards the organisation's goals, increased eagerness to deliver a higher level of service quality, low absenteeism, improved productivity, and increased productivity and employee morale and reduced stress. Therefore, the current study presents a fifth hypothesis, as follows:

Hypothesis 5 (H5). Organisational commitment has a significant effect on organisational performance sustainability. 


\subsection{Job Satisfaction Mediates the Relationship between Service Quality and Organisational Commitment}

Service quality management leads to internal (e.g., employee) and external (e.g., student) satisfaction, which, in turn, achieves organisational performance sustainability. Satisfaction can be achieved by integrating customer needs and wants into the firm's standards. These standards must be evaluated and updated continuously due to customers' needs and wants changing over time. Additionally, the bulk of previous studies revealed that service quality has a positive relationship with job satisfaction and organisational performance sustainability [58,59]. In the same vein, achieving job satisfaction in the organisation notably enhances organisational commitment in all employees. Moreover, service quality significantly increases organisational commitment among employees of the organisation [60]. Employee job satisfaction is a critical driver of employee organisational commitment in the education service industry due to its labour-intensive nature and the massive amount of resources allotted to employees to generate effectiveness, mainly through human factors [37]. Employee satisfaction and commitment in HEIs are important as these factors are the determinants of accountability and quality [37]. Previous studies have also proved that job satisfaction has a positive relationship with service quality [61], organisational performance sustainability [31,62], and organisation commitment $[60,63]$. Therefore, the current study presents two further hypotheses, as follows:

Hypothesis 6 (H6). Job satisfaction mediates the relationship between service quality and organisational performance.

Hypothesis 7 (H7). Job satisfaction mediates the relationship between service quality and organisational commitment.

\subsection{Organisational Commitment Mediates the Relationship between Job Satisfaction and Organisational Performance Sustainability}

Employee commitment has been identified as important for ensuring the successful implantation of service quality programmes [64]. Without commitment, service quality will fail. Commitment ensures that employees remain at and are loyal to the organisation and are committed to serving customers. Previous studies have revealed that commitment has a significant positive relationship with service quality $[65,66]$ and organisational performance sustainability $[41,50]$. Therefore, the current study suggests the final two hypotheses, as follows:

Hypothesis 8 (H8). Organisational commitment mediates the relationship between service quality and organisational performance sustainability.

Hypothesis 9 (H9). Organisational commitment mediates the relationship between job satisfaction and organisational performance sustainability.

\section{Methodology}

\subsection{Measurement of Constructs}

This study employed a structured questionnaire via a cross-sectional strategy. Items were adapted based on an intensive search of the literature to certify reliability and validity (Appendix A). The scales for service quality were adapted from [27], job satisfaction from [67], organisational commitment from [35], organisational performance sustainability using the dimensions of the Balanced Scorecard and items from [46], with reference to [68]. All items were measured using a seven-point Likert scale ranging from "strongly agree" to "strongly disagree" to provide more choices for the respondents to provide their opinions. This study employed a pilot test in which 100 heads of programmes were approached personally for questionnaire distribution and collection. The aforementioned sample comprised 50 respondents from Politeknik Sultan Salahuddin Abdul Aziz Shah, Shah Alam, and another 50 respondents from Politeknik Nilai, Negeri Sembilan. The convenience 
sampling technique was used to select heads of programmes with the same attributes as the real sample. The respondents completed the questionnaires within two weeks. Subsequently, the questionnaire proceeded to an exploratory factor analysis procedure.

\subsection{Data Collection and Samples}

All participants were from the departments of polytechnics in Malaysia. This study applied a proportionate simple random sampling technique due to the homogeneity of the sampling characteristics. The sampling frame was developed based on directories that are available on the polytechnics' websites. Malaysian polytechnics were selected due to the fact that they are the largest national TVET institutions facing organisational problems. The system only achieved $84 \%$ of the critical agenda in the Polytechnic Transformation Plan, according to an annual report published by the Department of Polytechnics Education [69], highlighting performance incompetence and poor service quality. This research aims to remedy the performance problems related to national human capital development sustainability.

Customers of an organisation must evaluate service quality. Since there is an unsettled debate regarding customer classification in higher education, the current study follows the classification given by [61] as it suits the research problem. Employees were classified as internal customers and students as external customers or education partners [61]. Hence, employees or internal customers refer to any authorised administrative personnel representing the departments (academic and non-academic) across the organisation. The administrative authorised personnel category also covers Heads of Departments (HoDs) due to their direct participation with employees in order to fulfil their needs and wants as part of department/organisational services to ensure that employees' duties can be carried out successfully. Heads of Departments are also aware of department operation, facilitate the needs and wants of staff, handle problems and monitor performance results, as well as employees' soft factors. Although staff are preferred as the informants of the organisation's service quality, empirical findings from other service settings have proved a correlation between the service provider's measures and actual customer ratings [67]. A set of 400 questionnaires were sent to HoDs through the Research and Innovation Unit at each polytechnic. The unit then distributed the questionnaire to targeted respondents. From 400 questionnaires distributed to HoDs, $214(214 / 400 \times 100=53 \%)$ were fit for the analysis. The descriptive analysis uncovered that the respondents were nearly balanced in terms of department type, with 91 (43\%) from academic and 123 (57\%) from non-academic departments. Most respondents (128 (60\%)) clarified that their department comprised 1-25 employees, 48 (22.5\%) clarified that their department comprised 26-50 employees, 37 (17\%) clarified that their department comprised 61-100, and $1(0.5 \%)$ clarified that their department comprised 101 employees or more. The majority of respondents were male $(135(63 \%))$, aged $31-40(43 \%)$, had served for $11-20$ years $(47 \%)$, and possessed a master's degree $(58.8 \%)$.

\subsection{Analysis}

The collected data were analysed using the Analysis of Moment Structure (AMOS) technique. This analysis method was used due to the explanatory nature of the study and the fact that it is able to test the model concurrently. To analyse the data, a two-step approach was used [70]. In the first step, using the measurement model, the validity and reliability of the variables were investigated. In the second step, the hypotheses were tested.

\section{Results}

\subsection{Assessment of the Measurement Model}

The measurement model of the study is depicted in Figure 2, showing the reliability and validity of the measured constructs. Table 1 displays the fulfilment of the fitness indexes, revealing that the model was fit for further analysis. Factor loading, composite reliability (CR), and the average variance extracted (AVE) were above 0.5, 0.6, and 0.5, 
respectively [71,72] (Table 2), thus confirming the convergent validity and reliability of the constructs [71].

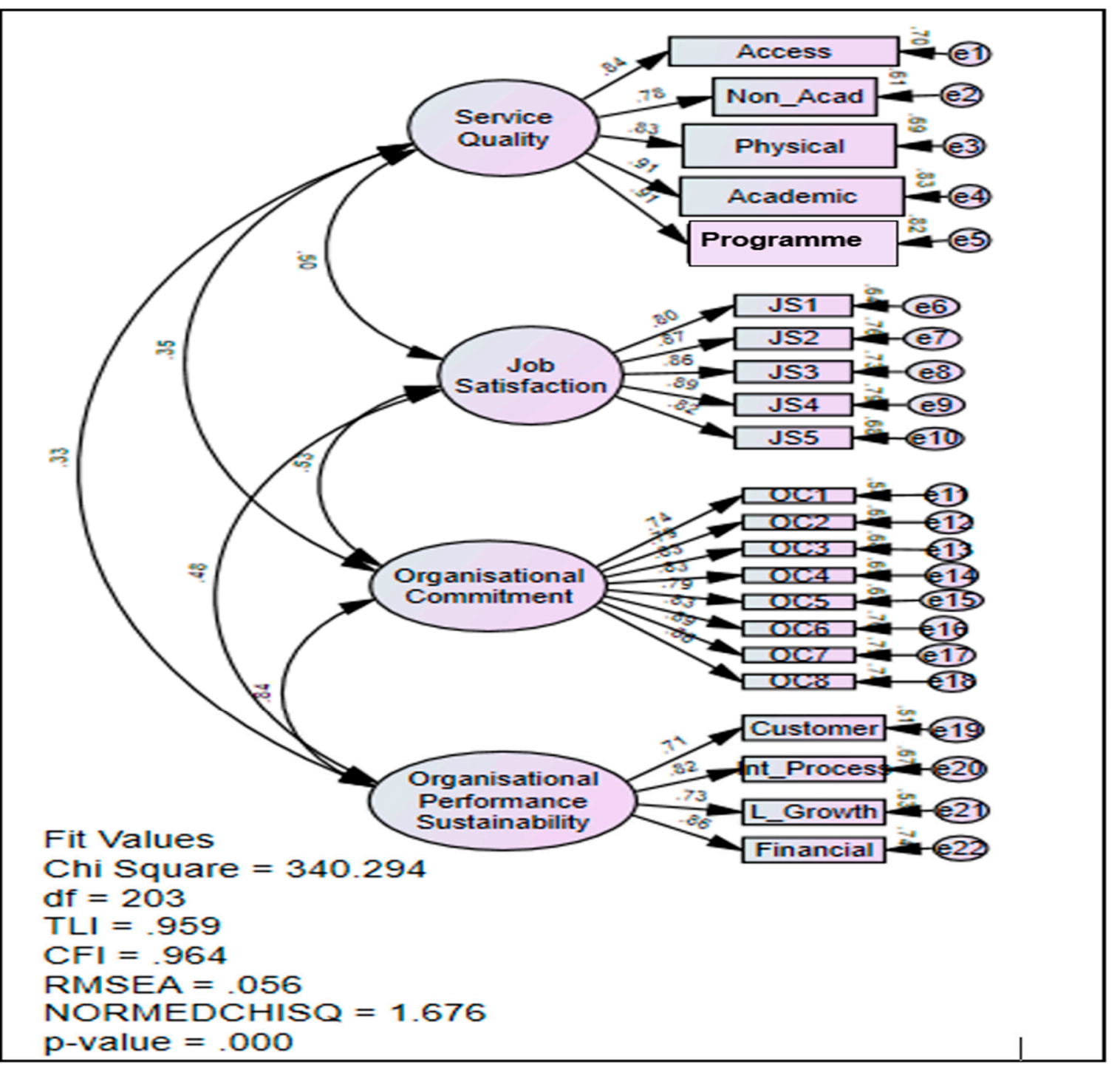

Figure 2. Measurement model.

Table 1. The results of the measurement model.

\begin{tabular}{lccccc}
\hline \multirow{2}{*}{ Fit Indices } & \multicolumn{2}{c}{ AFI } & \multicolumn{2}{c}{ IFI } & PFI \\
\cline { 2 - 6 } & $\begin{array}{c}\text { Relative Chi-Square } \\
(<5.0)\end{array}$ & $\begin{array}{c}\text { RMSEA } \\
(\leq \mathbf{0 . 0 8 0 )}\end{array}$ & $\begin{array}{c}\text { CFI } \\
(\geq \mathbf{0 . 9 0 0 )}\end{array}$ & $\begin{array}{c}\text { TLI } \\
(\geq \mathbf{0 . 9 0 0 )}\end{array}$ & $\begin{array}{c}\text { PGFI } \\
(\geq \mathbf{0 . 5 0 0 )}\end{array}$ \\
\hline Measurement model & 1.676 & 0.056 & 0.964 & 0.959 & 0.692 \\
\hline
\end{tabular}


Table 2. Analysis of convergent validity (AVE) and composite reliability (CR).

\begin{tabular}{|c|c|c|c|c|}
\hline Constructs & Items & Factor Loading & $\begin{array}{c}\text { CR } \\
\text { (above 0.6) }\end{array}$ & $\begin{array}{c}\text { AVE } \\
\text { (above 0.5) }\end{array}$ \\
\hline \multirow{5}{*}{ Service Quality } & Access & 0.837 & \multirow{5}{*}{0.931} & \multirow{5}{*}{0.731} \\
\hline & Non-Academic & 0.781 & & \\
\hline & Physical & 0.830 & & \\
\hline & Academic & 0.914 & & \\
\hline & Programme & 0.906 & & \\
\hline \multirow{5}{*}{ Job Satisfaction } & JS1 & 0.802 & \multirow{5}{*}{0.928} & \multirow{5}{*}{0.721} \\
\hline & JS2 & 0.873 & & \\
\hline & JS3 & 0.857 & & \\
\hline & JS4 & 0.887 & & \\
\hline & JS5 & 0.825 & & \\
\hline \multirow{8}{*}{$\begin{array}{l}\text { Organisational } \\
\text { Commitment }\end{array}$} & OC1 & 0.736 & \multirow{8}{*}{0.919} & \multirow{8}{*}{0.741} \\
\hline & OC2 & 0.788 & & \\
\hline & OC3 & 0.826 & & \\
\hline & OC4 & 0.829 & & \\
\hline & OC5 & 0.729 & & \\
\hline & OC6 & 0.834 & & \\
\hline & OC7 & 0.889 & & \\
\hline & OC8 & 0.862 & & \\
\hline \multirow{4}{*}{$\begin{array}{l}\text { Organisational } \\
\text { Performance } \\
\text { Sustainability }\end{array}$} & Customer & 0.713 & \multirow{4}{*}{0.862} & \multirow{4}{*}{0.611} \\
\hline & Int. Process & 0.819 & & \\
\hline & L. Growth & 0.727 & & \\
\hline & Financial & 0.859 & & \\
\hline
\end{tabular}

As stated in Table 3, by comparing the $\mathrm{r}^{2}$ with the AVE values, the $\mathrm{r}^{2}$ of all variables' values was less than the AVEs. Consequently, this indicated that each construct was distinct.

Table 3. The discriminant validity results.

\begin{tabular}{|c|c|c|c|c|c|}
\hline \multirow{2}{*}{ Variables } & \multirow{2}{*}{$\begin{array}{c}\text { Factor } \\
\text { Correlation }\end{array}$} & \multirow{2}{*}{$\begin{array}{l}\text { Correlation } \\
\text { Squared }\left(r^{2}\right)\end{array}$} & $\mathrm{AVE}_{1}$ & $\mathrm{AVE}_{2}$ & \multirow{2}{*}{$\begin{array}{l}\text { Discriminant } \\
\text { Validity }\end{array}$} \\
\hline & & & \multicolumn{2}{|c|}{ (AVEs Should Be $>r^{2}$ ) } & \\
\hline $\mathrm{SQ} \leftrightarrow \mathrm{JS}$ & 0.531 & 0.282 & 0.731 & 0.721 & VALID \\
\hline $\mathrm{SQ} \leftrightarrow \mathrm{OC}$ & 0.347 & 0.120 & 0.731 & 0.741 & VALID \\
\hline $\mathrm{SQ} \leftrightarrow \mathrm{OPS}$ & 0.331 & 0.110 & 0.731 & 0.611 & VALID \\
\hline$\widehat{\mathrm{JS}} \leftrightarrow \mathrm{OC}$ & 0.534 & 0.285 & 0.721 & 0.741 & VALID \\
\hline OC $\leftrightarrow$ OPS & 0.479 & 0.229 & 0.741 & 0.611 & VALID \\
\hline $\mathrm{JS} \leftrightarrow \mathrm{OPS}$ & 0.567 & 0.321 & 0.721 & 0.611 & VALID \\
\hline
\end{tabular}

\subsection{Testing of Normality of Constructs}

This study evaluated data distribution normality before running the structural model. The skewness value for the current data was $-1.5-1.5$, which, for sample sizes greater than 200 , is accepted as normally distributed [71].

\subsection{The Assessment of Common Method Variance (CMV)}

Harman's One Factor test was used to determine any issues with the common method variance. To conduct Harman's One Factor test, two models were developed, i.e., Harman's One Factor model and a measurement model. Then, the model fit of Harman's One Factor model was compared with the model fit of the proposed measurement model. If Harman's One Factor model had a poorer fit than the proposed model, common method variance would not be present [73]. Table 4 shows that the goodness-of-fit indices of Harman's One Factor model had a poorer fit than the proposed measurement model, confirming that the common method variance was not a problem in this study [73]. 
Table 4. Common method variance results.

\begin{tabular}{lccccc}
\hline & \multicolumn{2}{c}{ AFI } & \multicolumn{2}{c}{ IFI } & PFI \\
\cline { 2 - 6 } Fit Indices & $\begin{array}{c}\text { Relative Chi-Square } \\
(<5.0)\end{array}$ & $\begin{array}{c}\text { RMSEA } \\
(\leq \mathbf{0 . 0 8 0})\end{array}$ & $\begin{array}{c}\text { CFI } \\
(\geq \mathbf{0 . 9 0 0 )}\end{array}$ & $\begin{array}{c}\text { TLI } \\
(\geq \mathbf{0 . 9 0 0 )}\end{array}$ & $\begin{array}{c}\text { PGFI } \\
(\geq \mathbf{0 . 5 0 0 )}\end{array}$ \\
\hline $\begin{array}{l}\text { Harman's One Factor } \\
\text { Model }\end{array}$ & 8.452 & 0.187 & 0.589 & 0.546 & 0.379 \\
Measurement Model & 1.676 & 0.056 & 0.964 & 0.959 & 0.692 \\
\hline
\end{tabular}

\subsection{Assessment of the Structural Model}

The model of service quality, job satisfaction and organisational commitment managed to explain $\sim 73 \%$ of the variance of the organisational performance, as shown in Figure 3. Table 5 displays the fulfilment of the fitness indexes, showing that the model was fit for further testing. The regression coefficients for all constructs are presented in Table 6 , showing that service quality impacted job satisfaction, job satisfaction impacted organisational commitment, and organisational commitment impacted organisational performance sustainability. Therefore, $\mathrm{H} 1, \mathrm{H} 4$, and $\mathrm{H} 5$ were supported, whereas $\mathrm{H} 2$ and $\mathrm{H} 3$ were not.

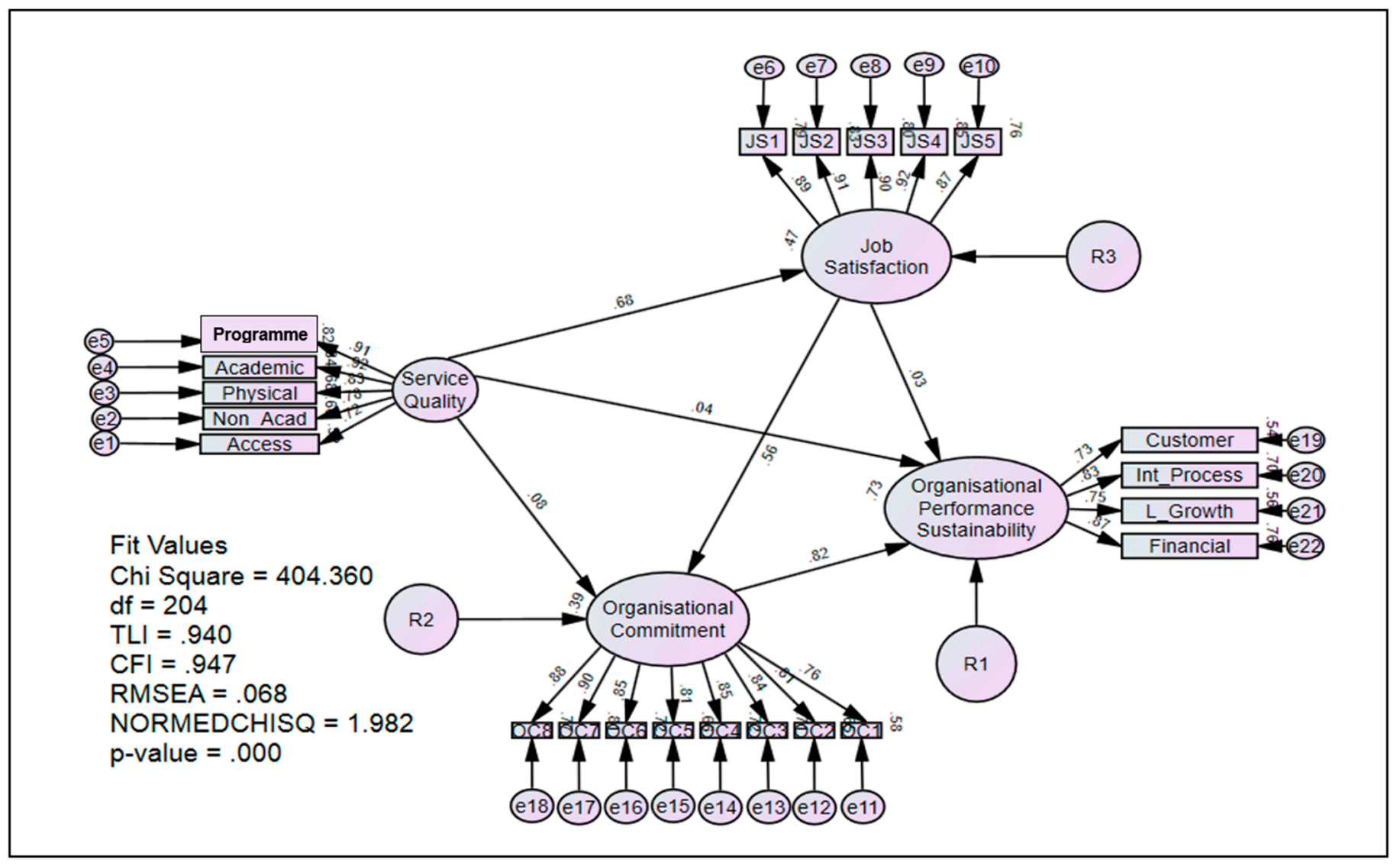

Figure 3. Structural model.

Table 5. Structural model results.

\begin{tabular}{lccccc}
\hline \multirow{2}{*}{ Fit Indices } & \multicolumn{2}{c}{ AFI } & \multicolumn{2}{c}{ IFI } & PFI \\
\cline { 2 - 6 } & $\begin{array}{c}\text { Relative Chi-Square } \\
(<5.0)\end{array}$ & $\begin{array}{c}\text { RMSEA } \\
(\leq \mathbf{0 . 0 8 0 )}\end{array}$ & $\begin{array}{c}\text { CFI } \\
(\geq \mathbf{0 . 9 0 0 )}\end{array}$ & $\begin{array}{c}\text { TLI } \\
(\geq \mathbf{0 . 9 0 0 )}\end{array}$ & $\begin{array}{c}\text { PGFI } \\
(\geq \mathbf{0 . 5 0 0 )}\end{array}$ \\
\hline Structural model & 1.982 & 0.068 & 0.947 & 0.940 & 0.682 \\
\hline
\end{tabular}


Table 6. Testing results of the hypotheses $(\mathrm{H} 1-\mathrm{H} 5)$.

\begin{tabular}{ccccccc}
\hline Hypotheses & Causal Path & Estimate & S.E. & C.R. & $p$-Value & Decision \\
\hline $\mathrm{H}_{1}$ & $\mathrm{SQ} \rightarrow$ JS & 1.000 & & & & Supported \\
\hline $\mathrm{H}_{2}$ & $\mathrm{SQ} \rightarrow$ OC & 0.077 & 0.078 & 0.994 & 0.320 & $\begin{array}{c}\text { Not } \\
\text { supported }\end{array}$ \\
\hline $\mathrm{H}_{3}$ & $\mathrm{JS} \rightarrow$ OP & 0.023 & 0.051 & 0.450 & 0.653 & $\begin{array}{c}\text { Not } \\
\text { supported }\end{array}$ \\
\hline $\mathrm{H}_{4}$ & $\mathrm{JS} \rightarrow$ OC & 0.358 & 0.058 & 6.212 & $* * *$ & Supported \\
\hline $\mathrm{H}_{5}$ & $\mathrm{OC} \rightarrow$ OP & 0.881 & 0.099 & 8.874 & $* * *$ & Supported \\
\hline -Value $<0.005$. & & & & & &
\end{tabular}

This study employed bootstrapping to confirm the mediation effect from the results of the ordinary mediating effect using the Maximum Likelihood (ML) procedure with 1000 bootstrap samples, a percentile confidence interval of $95 \%$ and a bias-corrected confidence interval of 95\% [71,72]. According to Table 7, job satisfaction fully mediated the relationship between service quality and organisational commitment, and organisational commitment fully mediated the relationship between job satisfaction and organisational performance sustainability. As such, H7 and H9 were supported, and the rest were not.

Table 7. Mediation effects of soft factors.

\begin{tabular}{|c|c|c|c|c|c|}
\hline \multirow{2}{*}{ Paths } & \multirow[b]{2}{*}{$\beta$} & \multirow[b]{2}{*}{$p$-Value } & \multicolumn{2}{|c|}{ 95\% Bootstrap BC } & \multirow[b]{2}{*}{ Decision } \\
\hline & & & LB & UB & \\
\hline Direct model H6 (SQ $\rightarrow$ OPS) & 0.036 & 0.008 & \multirow{4}{*}{0.164} & \multirow{4}{*}{0.363} & \multirow{4}{*}{ Not Supported } \\
\hline Mediation Model & 0.406 & 0.006 & & & \\
\hline Standardised Indirect Effect (SIE) & 0.019 & 0.607 & & & \\
\hline \multicolumn{3}{|l|}{ H6: (SQ $\rightarrow$ JS $\rightarrow$ OPS) } & & & \\
\hline Direct model H7 (SQ $\rightarrow$ OC) & 0.083 & 0.088 & & & \multirow{4}{*}{$\begin{array}{l}\text { Supported- } \\
\text { Full Mediation }\end{array}$} \\
\hline Mediation Model & 0.384 & 0.075 & & & \\
\hline Standardised Indirect Effect (SIE) & 0.301 & 0.004 & 0.131 & 0.301 & \\
\hline \multicolumn{5}{|l|}{$\mathrm{H} 7:(\mathrm{SQ} \rightarrow \mathrm{JS} \rightarrow \mathrm{OC})$} & \\
\hline Direct model H8 (SQ $\rightarrow$ OPS) & 0.036 & 0.008 & & & \multirow{4}{*}{ Not Supported } \\
\hline Mediation Model & 0.406 & 0.006 & & & \\
\hline Standardised Indirect Effect (SIE) & 0.112 & 0.077 & 0.24 & 0.412 & \\
\hline \multicolumn{5}{|l|}{ H8: (SQ $\rightarrow$ OC $\rightarrow$ OPS) } & \\
\hline Direct model H9 (JS $\rightarrow$ OPS) & 0.034 & 0.078 & & & \multirow{4}{*}{$\begin{array}{l}\text { Supported- } \\
\text { Full Mediation }\end{array}$} \\
\hline Mediation Model & 0.315 & 0.87 & & & \\
\hline Standardised Indirect Effect (SIE) & 0.384 & 0.004 & 0.199 & 0.384 & \\
\hline H9: (JS $\rightarrow$ OC $\rightarrow$ OPS) & & & & & \\
\hline
\end{tabular}

\section{Discussion}

The model of service quality, job satisfaction and organisational commitment managed to explain $\sim 73 \%$ of the variance of the organisational performance sustainability. The regression coefficients for all constructs are presented in Table 6, showing that service quality impacted job satisfaction, job satisfaction impacted organisational commitment, and organisational commitment impacted organisational performance sustainability. Therefore, $\mathrm{H} 1, \mathrm{H} 4$ and $\mathrm{H} 5$ were supported, whereas $\mathrm{H} 2$ and $\mathrm{H} 3$ were not. For the mediation effect, job satisfaction fully mediated the relationship between service quality and organisational commitment, and organisational commitment fully mediated the relationship between job satisfaction and organisational performance sustainability. As such, $\mathrm{H} 7$ and $\mathrm{H} 9$ were supported, and the rest were not.

Hypothesis 1 (H1)_SQ-JS supported. 
The significant impact of service quality on job satisfaction was in line with previous studies [37,74], which advocate for the implementation of service quality to improve job satisfaction among internal customers. Service quality practices involving academic aspects, physical facilities, access, programme issues and non-academic aspects are needed to generate job satisfaction due to the fulfilment of internal customer needs and wants. The fulfilment of their needs and wants is essential as this leads to employees successfully delivering a high-quality daily operation service for external customers in TVET institutions. Therefore, polytechnics' implementation of service quality by fulfilling internal customers' needs and wants can enhance job satisfaction among internal customers in the TVET education sector.

Hypothesis 2 (H2)-SQ-OC not supported.

Unexpectedly, little support was discovered for $\mathrm{H} 2$ concerning the implementation of service quality increasing organisational commitment. The survey data do not support the implementation of service quality with a focus on internal customers' organisational commitment. This finding differs from other studies in which scholars found that internal service quality improved the commitment among employees of an organisation [30,42]. A possible explanation for this is that the nature of the implementation of service quality is based on top-down instruction from the government. Within government-owned institutions such as the polytechnics, pursuing service quality improves internal processes for service delivery in all operations. Therefore, the implementation of service quality cannot retain employees and leverage performance via their organisational commitment.

\section{Hypothesis 3 (H3)_-JS-OP not supported.}

Job satisfaction was ascertained to have no significant effect on organisational performance, leading to the rejection of H3. This finding was not consistent with past studies relating to job satisfaction showing a positive link with organisational performance $[47,49]$. This difference was possibly due to the research context factor, such as the fact that for-profit organisations were assessed. One study was conducted in tourism and private hospital settings [47], whereas another was conducted in the banking system [49].

In disagreement with what was predicted, the current study discovered that increased levels of job satisfaction did not directly enhance organisational performance. Additionally, the relationship between job satisfaction and organisational performance was not as straightforward, so perhaps other dimensions should be considered. Service employees who feel connected and satisfied with the organisation are a source of value to the firm, making them eager to serve external customers and enhance firm performance $[75,76]$.

A credible reason for this based on the results of this study is that the operational conditions for the non-profit sector (i.e., polytechnics provide the public with access to higher education) may not always be compatible with the application of management tools developed in other sectors. There is a higher risk for the for-profit sector than the non-profit sector, as the non-profit sector appears to be governed largely by the nature of its environment, which often relies upon the stability of service provision [77]. Hence, it seems that job satisfaction is not significant at the department level in individual polytechnics.

Hypothesis 4 (H4)-JS-OC supported.

This study revealed a significant relationship between job satisfaction and organisational values and goals, postulating evidence to support $\mathrm{H} 4$. The findings of this study are also consistent with others $[37,60]$. Committed employees are anticipated to acknowledge and trust in organisational purposes and values, wishing to remain within their organisations and work hard on their behalf [37].

\section{Hypothesis 5 (H5) - OC-OP supported.}

In response to the fifth hypothesis of this study, as expected, organisational commitment was found to have a significant positive effect on organisational performance sustainability. This finding is consistent with others in that organisational commitment has a positive link with performance sustainability $[43,57]$. The literature findings also confirm 
the results of this study in that commitment at all levels of the organisation, specifically the Heads of Departments, is a prerequisite to obtaining organisational performance sustainability. Internal customers are an important determinant in the input-process-output chain in the polytechnic system and, thus, their commitment cannot be ignored. In summary, the commitment of external customers (i.e., students and parents) must be preceded by the commitment of internal customers.

Hypotheses 6 (H6) and 7 (H7) - The mediating effect of job satisfaction.

It has been asserted that the relationship between quality and organisational performance occurs indirectly through other variables $[4,14]$. Amazingly, this study showed that job satisfaction does not appear to be a mediator influencing organisational performance sustainability, as expected. Thus, $\mathrm{H} 6$ was not supported. The present result was not in line with others, which reported that satisfaction was a mediator between quality and organisational performance $[13,14]$. From this finding, we may conclude that the path from service quality to organisational performance sustainability cannot be established through job satisfaction. The achievement of job satisfaction did not lead to improved organisational performance sustainability. The possible reason for this is that the path from service quality to job satisfaction tends to be long when it comes to reaching organisational performance sustainability, in light of the fact that sustainability is found at the strategic performance level in any organisation.

As expected, this study found that job satisfaction fully mediated the relationship between service quality and organisational commitment, supporting H7. This proposes that total commitment from an employee can be achieved by sustaining their job satisfaction. Based on the results, this study indicates that, for any organisation that applies service quality to employees in producing their services and products, job satisfaction plays a key role in their service quality implementation style, which can, in turn, enhance organisational commitment.

Hypotheses 8 (H8) and 9 (H9) - The mediating effect of organisational commitment.

Surprisingly, this study established that organisational commitment does not mediate service quality and organisational performance as expected. Thus, $\mathrm{H} 8$ was not supported. Accordingly, this study provides evidence that is not consistent with previous studies in which organisational commitment was suggested to significantly affect and mediate quality and organisational performance $[42,43]$. This result reveals that service quality was unable to increase commitment in order to achieve organisational performance sustainability.

The results suggest that uncommitted management and employees are severe problems when implementing a quality initiative to achieve organisational performance sustainability. Other studies also support the fact that the problems that arise in terms of gaining commitment are related to individuals' characteristics, such as perceptions, attitudes, expectations, and values [13]. These are constructs that could obstruct acceptance of and motivation to work with the implementation of service quality. Subsequently, intangible factors such as salary, relationship with the organisation and employee well-being are important for securing employees' commitment, in that they affect behavioural characteristics and create job-related attitudes [13]; however, organisational commitment is more stable over time and develops more slowly within organisations [13].

On the other hand, organisational commitment fully mediated the links between job satisfaction and organisational performance sustainability, supporting H9. This analysis exposes the fact that one of the strategies that Heads of Departments can employ to enhance organisational performance sustainability is sustaining organisational commitment. Organisational commitment can be sustained through the achievement of job satisfaction.

Therefore, reflecting on the system theory that this study was based on, the input will lead to the achievement of the process stage, and the attainment of the process stage will enhance the output stage. Thus, the implementation of service quality enhances job satisfaction. The achievement of job satisfaction subsequently increases organisational commitment at the process stage. The achievement of organisational commitment ultimately 
develops the organisational performance of the entire polytechnic system as the outputs of the input and process stages.

This research supports the underpinning theory that there is a significant impact on service quality that further enhances soft factors interdependently to create a positive outcome in terms of organisational performance sustainability. In more detail, the main aim of service quality is to help an organisation to consistently achieve customer satisfaction (internal and external). Through effective and efficient service quality implementation, internal customers' needs and wants in relation to academic aspects, non-academic aspects, access, programme issues and physical facilities are reflected in the enhancement of their job satisfaction. Internal customers complete their work with the understanding that the polytechnic will respond by providing them with benefits and other positive rewards. Subsequently, an improvement in their job satisfaction will affect their participation, meaning that they will become more committed and loyal to the organisation. Accordingly, internal customers deliver a good quality of service, and reduce complaints and dissatisfaction among external customers, promoting the sustainability of the organisation's performance.

\section{Conclusions}

This study aimed to examine the relationship between service quality and organisational performance sustainability in the TVET education system when job satisfaction and organisational commitment are mediating factors. Our findings advocate for the fact that service quality has a positive and significant effect on job satisfaction, job satisfaction has a positive and significant effect on organisational commitment, and organisational commitment has a positive and significant effect on organisational performance sustainability.

This study contributes to the research on organisational performance sustainability in terms of its theory, methodology, and practicality. Concerning its contribution to theory, this research used a modified education-specific HEdPERF model, which measures context-specific issues. This study also extends the literature on operation management by recognising the roles of soft factors in enhancing performance sustainability when improving service quality in an organisation. A contribution is also made via our assessment of the impact of service quality and soft factors on an organisation's performance sustainability. This study was able to reveal the path from service quality to organisational performance sustainability in a single model. Secondly, this study achieved validity and reliability and a better fitting model in contribution to the methodology. The respondents chosen were the correct personnel to respond to the questionnaire because Heads of Departments are managers that hold important roles in sustaining quality and performance improvements in an organisation. Therefore, their consultation has contributed to the development of accurate and credible research findings. In terms of practical implications, the research model can serve as a guideline for managers in TVET institutions. We provide a comprehensive assessment of how service quality might be improved by paying particular attention to internal customers through job satisfaction and organisational commitment. Likewise, this study offers evidence that job satisfaction is a necessary precondition for organisational commitment, which is a key driver of organisational performance sustainability. To become successful organisations, we urge firms to pay close attention to job satisfaction pressures, which cause increased organisational commitment. Heads of Departments must appreciate their employees' soft factors to maintain the organisation's competitive edge. Thus, knowing how employees feel about their jobs will help managers to develop appropriate strategies focusing on job satisfaction and organisational commitment. In summary, department heads must focus on planning and preparing a strategy to engage internal customers that can subsequently enhance their soft factors and encourage organisational sustainability.

Although the current study achieved its aims, a few limitations should be considered when generalising the findings. This current research is a cross-sectional study, and data were gathered over a certain period, so they could not show the patterns and trends of the relationship between soft factors and organisational performance sustainability. Thus, a 
longitudinal study should be conducted to develop a better picture. Secondly, this study lacked employee data; hence, future studies should survey employees of the organisations for a broader illustration and more conclusive findings. Finally, the data were gathered from Malaysian polytechnic TVET institutions and did not include private higher education institutions and local universities, which is a common issue in a context-specific study due to the peculiarities of service settings, which require their own frameworks. Future studies should cover a broader context of education services, including community colleges, private skills training institutes, and private HEIs. This will enable more understanding regarding the impact of the modified HEdPERF model as an industry-specific measurement model on soft factors and the performance sustainability of organisations.

Author Contributions: Conceptualisation, S.M.K. and K.A.M.A.; Data curation, S.M.K.; Formal analysis, K.A.M.A. and S.D.M.W.; Funding acquisition, Z.K.M.M.; Methodology, S.M.K., K.A.M.A. and S.D.M.W.; Writing—original draft, S.M.K. and K.A.M.A.; Writing-review and editing, Z.K.M.M. and M.H.A. All authors have read and agreed to the published version of the manuscript.

Funding: This research is funded by Malaysian Ministry of Higher Education, Fundamental Research Grant Scheme (FRGS), research code: FRGS/1/2020/SS02/UKM/01/1 and Dana Pecutan Penerbitan GSB, research code: PP-GSB-2021.

Institutional Review Board Statement: Not applicable.

Informed Consent Statement: Not applicable.

Data Availability Statement: Not applicable.

Conflicts of Interest: The authors declare no conflict of interest.

\section{Appendix A. Questionnaire}

\begin{tabular}{ll}
\hline & Item Statement for Service Quality \\
\hline NA1 & Sincere interest in solving problem \\
\hline NA2 & Individualised attention \\
\hline NA3 & Efficient/prompt at dealing with complaints \\
\hline NA4 & Accurate and retrievable records \\
\hline NA5 & Promises kept \\
\hline NA6 & Positive attitude \\
\hline NA7 & Good communication \\
\hline NA8 & Knowledge of the systems/procedures \\
\hline NA9 & Equal treatment and respect \\
\hline NA10 & Confidentiality of information \\
\hline AC1 & Knowledgeable about course content \\
\hline AC2 & Caring and courteous \\
\hline AC3 & Sincere interest in solving problems \\
\hline AC4 & Positive attitude \\
\hline AC5 & Good communication \\
\hline AC6 & Feedback on progress \\
\hline AC7 & Educated and experience academicians \\
\hline AC8 & Sufficient and convenient consultation \\
\hline
\end{tabular}




\begin{tabular}{|c|c|}
\hline & Item Statement for Service Quality \\
\hline PG1 & Excellent quality programmes \\
\hline PG2 & Wide range of programmes with various specialisations \\
\hline PG3 & Counselling services \\
\hline PG4 & Reputable academic programmes \\
\hline PG5 & Minimal class sizes \\
\hline PG6 & Variety of programmes/specialisations \\
\hline PH1 & Facilities and equipment \\
\hline $\mathrm{PH} 2$ & Library and resource centre \\
\hline PH3 & Well equipped with modern facilities \\
\hline PH4 & Aesthetic view of facilities \\
\hline PH5 & A well-equipped communication building \\
\hline PH6 & Adequate facilities/infrastructure to render service \\
\hline PH7 & Comprehensive learning sources \\
\hline PH8 & Professional appearance/image \\
\hline AS1 & Responding to requests for assistance \\
\hline AS2 & Sufficient time for consultation \\
\hline AS3 & Easily contactable \\
\hline AS4 & Knowledgeable when responding \\
\hline AS5 & Expresses opinions \\
\hline AS6 & Staff union \\
\hline AS7 & Feedback for improvement \\
\hline AS8 & Service delivery procedures \\
\hline \multirow[t]{2}{*}{ AS9 } & Convincing website \\
\hline & Item Statement for Job Satisfaction \\
\hline JS1 & Salary \\
\hline JS2 & Promotion \\
\hline JS3 & Nature of the job \\
\hline JS4 & Relationship with colleagues \\
\hline \multirow[t]{2}{*}{ JS5 } & Relationship with supervisor \\
\hline & Item Statement for Organisation Commitment \\
\hline OC1 & Plans to spend the rest of their career at the institution \\
\hline OC2 & Enjoys discussing the polytechnic \\
\hline OC3 & Organisational problems \\
\hline OC4 & Attached to organisation \\
\hline OC5 & Part of the family \\
\hline OC6 & Emotionally attached \\
\hline OC7 & Personally attached \\
\hline OC8 & Sense of belonging \\
\hline
\end{tabular}




\begin{tabular}{ll}
\hline & Item Statement for Organisational Performance Sustainability \\
\hline FN1 & Service and management costs \\
\hline FN2 & Commercial income (rental, testing, services, etc.) \\
\hline FN3 & Increasing productivity \\
\hline FN4 & Budget management \\
\hline FN5 & Sufficient budget \\
\hline IP1 & Compliments and recognition \\
\hline IP2 & Suggests changes or modifications \\
\hline IP3 & Products/services improvement \\
\hline IP4 & Continuous study and improvement \\
\hline IP5 & Services are improved continuously \\
\hline LG1 & An environment that encourages continuous education \\
\hline LG2 & Delivers services and deals with employees or external customers \\
\hline LG3 & A work environment that encourages employees to perform \\
\hline LG4 & Motivates staff and encourages a positive performance \\
\hline CS1 & Satisfying our customers \\
\hline CS2 & Satisfying customers and meeting expectations \\
\hline CS3 & Knows what customers expect \\
\hline CS4 & Customer complaints \\
\hline
\end{tabular}

\section{References}

1. Jabarullah, N.H.; Hussain, H.I. The effectiveness of problem-based learning in technical and vocational education in Malaysia. Educ. Train. 2019, 61, 552-567. [CrossRef]

2. Prikshat, V.; Montague, A.; Connell, J.; Burgess, J. Australian graduates' work readiness-deficiencies, causes and potential solutions. High Edu. Skills Work-Based Learn. 2020, 10, 369-386. [CrossRef]

3. Khalid, S.M.; Mohd Ali, K.A.; Makhbul, Z.K.M. Assessing the effect of higher education service quality on job satisfaction among lecturers in premier polytechnics using HEdPERF model. LogForum 2019, 15, 425-436. [CrossRef]

4. Basu, R.; Bhola, P.; Ghosh, I.; Dan, P.K. Critical linkages between quality management practices and performance from Indian IT enabled service SMEs. Total Qual. Manag. Bus. Excel. 2016, 29, 881-919. [CrossRef]

5. Khalaf, M.A.; Khourshed, N. Performance-based service quality model in postgraduate education. Int. J. Qual. Reliab. Manag. 2017, 34, 626-648. [CrossRef]

6. Fotopoulos, C.B.; Psomas, E.L. The impact of "soft" and "hard" TQM elements on quality management results. Int. J. Qual. Reliab. Manag. 2009, 26, 150-163. [CrossRef]

7. Habtoor, N.; Alharbi, A.A. Importance of human factors to organizational performance. Int. J. Manag. Hum. Sci. 2020, 4, 11-22.

8. Wayhan, V.B.; McCallum, M.F.; Golyer, N.M. TQM and financial performance: Are findings of direct effects methodological artefacts? Total Qual. Manag. Bus. Excel. 2013, 24, 171-187. [CrossRef]

9. Oliveira, G.; Corrêa, J.; Balestrassi, P.; Martins, R.; Turrioni, J.B. Investigation of TQM implementation: Empirical study in Brazilian ISO 9001-registered SMEs. Total Qual. Manag. Bus. Excel. 2019, 30, 641-659. [CrossRef]

10. Nair, G.K.; Choudhary, N. The Impact of Service Quality on Business Performance in Qatar-Based Hotels: An Empirical Study. J. Hosp. Financ. Manag. 2016, 24, 47-67. [CrossRef]

11. Zeng, J.; Zhang, W.; Matsui, Y.; Zhao, X. The impact of organizational context on hard and soft quality management and innovation performance. Int. J. Prod. Econ. 2017, 185, 240-251. [CrossRef]

12. Frimpong, K.; Wilson, A. Relative importance of satisfaction dimensions on service performance. J. Serv. Manag. 2013, 24, 401-419. [CrossRef]

13. Sharma, P. Internal service quality as a driver of employee satisfaction, commitment and performance: Exploring the focal role of employee well-being. J. Serv. Manag. 2016, 27, 773-797. [CrossRef]

14. Yoo, D.K.; Park, J.A. Perceived service quality: Analyzing relationships among employees, customers, and financial performance. Int. J. Qual. Reliab. Manag. 2007, 24, 908-926. [CrossRef]

15. Sciarelli, M.; Gheith, M.H.; Tani, M. The relationship between soft and hard quality management practices, innovation and organizational performance in higher education. TQM J. 2020, 32, 1349-1372. [CrossRef]

16. Evans, J.R.; Linsay, W.M. Managing for Quality and Performance Excellence, 12th ed.; Cengage Learning: Boston, MA, USA, 2014. 
17. Deming, W.E. Out of the Crisis: Quality, Productivity and Competition Position; Cambridge University Press: Cambridge, UK, 1986.

18. Boer, H.; Holweg, M.; Kilduff, M.; Pagell, M.; Schmenner, R.W.; Voss, C. Making a meaningful contribution to theory. Int. J. Oper. Prod. Manag. 2015, 35, 1231-1252. [CrossRef]

19. Mehralizadeh, Y.; Safaeemoghaddam, M. The applicability of quality management systems and models to higher education: A new perspective. TQM J. 2010, 22, 175-187. [CrossRef]

20. Mele, C.; Pels, J.; Polese, F. A Brief Review of Systems Theories and Their Managerial Applications. Serv. Sci. 2010, 2, 126-135. [CrossRef]

21. Jackson, M.C. System Approaches to Management; Kluwer Academic/Plenum Publisher: New York, NY, USA, 2000.

22. Parasuraman, A.; Zeithaml, V.A.; Berry, L.L. SERVQUAL: A multiple-item scale for measuring consumer perceptions of service quality. J. Retail. 1988, 64, 12-40. [CrossRef]

23. Silva, D.S.; Hermínio, G.; Marcondes, S.; Makiya, I.K.; Giocondo, F.I. Meaurement of perceived service quality in higher eduction institutions: A review of HEdPERF scale use. Qual. Assur. Edu. 2017, 25, 415-439. [CrossRef]

24. Abdullah, F. HEdPERF versus SERVPERF. Qual. Assur. Educ. 2005, 13, 305-328. [CrossRef]

25. Ushantha, R.A.C.; Kumara, P.S. A Quest for Service Quality in Higher Education: Empirical Evidence from Sri Lanka. Serv. Mark. Q. 2016, 37, 98-108. [CrossRef]

26. Alfy, S.E.; Abukari, A. Revisiting perceived service quality in higher education: Uncovering service quality dimensions for postgraduate students. J. Mark. High Edu. 2019, 30, 1-25. [CrossRef]

27. Ali, F.; Zhou, Y.; Hussain, K.; Nair, P.K.; Ragavan, N.A. Does higher education service quality effect student satisfaction, image and loyalty? Qual. Assur. Educ. 2016, 24, 70-94. [CrossRef]

28. Mang'unyi, E.E.; Govender, K.K. Using the higher education performance framework to assess service quality and satisfaction among private university students. Int. Rev. Manag. Mark. 2017, 7, 299-309.

29. Shukla, Y.S.; Gadhavi, D.D.; Patel, J.D. Role of information of service quality in formation of behavioural intention among students: Empirical analysis in university settings. Int. J. Serv. Econ. Manag. 2018, 9, 61. [CrossRef]

30. Arunachalam, T.; Palanichamy, Y. Does soft aspects of TQM influence job satisfaction and commitment? An empirical analysis. TQM J. 2017, 29, 1-41. [CrossRef]

31. Heskett, J.L.; Jones, T.O.; Loveman, G.W.; Sasser, W.E.; Schlesinger, L.A. Putting the Service-Profit Chain to work. Harv. Buss. Rev. 1994, 7-8, 118-129. [CrossRef]

32. Hogreve, J.; Iseke, A.; Derfuss, K.G.; Eller, T.F. The Service-Profit Chain: A Meta-Analytic Test of a Comprehensive Theoretical Framework. J. Mark. 2017, 81, 41-61. [CrossRef]

33. Jyoti, J.; Kour, S.; Sharma, J. Impact of total quality services on financial performance: Role of service profit chain. Total Qual. Manag. Bus. Excel. 2015, 28, 897-929. [CrossRef]

34. Guimaraes, T. TQM's impact on employee attitudes. TQM Maga. 1996, 8, 20-25. [CrossRef]

35. Allen, N.J.; Meyer, J.P. The Measurement and Antecendent of Affective Continuance and Normative Commitment. J. Occup. Psycho. 1990, 63, 1-18. [CrossRef]

36. Meyer, J.P.; Stanley, D.J.; Herscovitch, L.; Topolnytsky, L. Affective, Continuance, and Normative Commitment to the Organization: A Meta-analysis of Antecedents, Correlates, and Consequences. J. Vocat. Behav. 2002, 61, 20-52. [CrossRef]

37. Trivellas, P.; Santouridis, I. Job satisfaction as a mediator of the relationship between service quality and organisational commitment in higher education. An empirical study of faculty and administration staff. Total Qual. Manag. Bus. Excel. 2014, 27, 169-183. [CrossRef]

38. Trivellas, P.; Dargenidou, D. Organisational culture, job satisfaction and higher education service quality. TQM J. 2009, 21, 382-399. [CrossRef]

39. Yee, R.W.Y.; Yeung, A.C.L.; Cheng, T.C.E. An empirical study of employee loyalty, service quality and firm performance in the service industry. Int. J. Prod. Econ. 2010, 124, 109-120. [CrossRef]

40. Tan, C.N.-L.; Ojo, A.; Cheah, J.-H.; Ramayah, T. Measuring the Influence of Service Quality on Patient Satisfaction in Malaysia. Qual. Manag. J. 2019, 26, 129-143. [CrossRef]

41. Hadi, N.U.; Aslam, N.; Gulzar, A. Sustainable Service Quality and Customer Loyalty: The Role of Customer Satisfaction and Switching Costs in the Pakistan Cellphone Industry. Sustainability 2019, 11, 2408. [CrossRef]

42. Yu, Q.; Yen, D.A.; Barnes, B.R.; Huang, Y.-A. Enhancing firm performance through internal market orientation and employee organizational commitment. Int. J. Hum. Resour. Manag. 2017, 30, 964-987. [CrossRef]

43. Hilal, M.I.M. Exploring the impacts of internal marketing practices and employees' organisational commitment: Special reference to hotel industry in Sri Lanka. Middle East J. Manag. 2020, 7, 611. [CrossRef]

44. Kaynak, H. The relationship between total quality management practices and their effects on firm performance. J. Oper. Manag. 2003, 21, 405-435. [CrossRef]

45. Adem, M.K.; Virdi, S.S. The effect of TQM practices on operational performance: An empirical analysis of ISO $9001: 2008$ certified manufacturing organizations in Ethiopia. TQM J. 2020, 33, 407-440. [CrossRef]

46. Wang, C.-J.; Tseng, K.-J. Effects of Selected Positive Resources on Hospitality Service Quality: The Mediating Role of Work Engagement. Sustainability 2019, 11, 2320. [CrossRef]

47. Kong, H.; Jiang, X.; Chan, W.; Zhou, X. Job satisfaaction research in the field of hospitality and tourism. Int. J Contemp. Hosp. Manag. 2018, 30, 2178-2194. [CrossRef] 
48. Teh, P.-L.; Ooi, K.-B.; Yong, C.-C. Does TQM impact on role stressors? A conceptual model. Ind. Manag. Data Syst. 2008, 108, 1029-1044. [CrossRef]

49. Golovkova, A.; Eklof, J.; Malova, A.; Podkorytova, O. Customer satisfaction index and financial performance: A European cross country study. Int. J. Bank Mark. 2019, 37, 479-491. [CrossRef]

50. Eklof, J.; Hellstrom, K.; Malova, A.; Parmler, J.; Podkorytova, O. Customer perception measures driving financial performance: Theoretical and empirical work for a large decentralized banking group. Meas. Bus. Excel. 2017, 21, 239-249. [CrossRef]

51. Rodrigues, A.P.; Pinho, J.C.M.R. Market orientation, job satisfaction, commitment and organisational performance: The specific case of local sector. Transform. Gov. People Process. Policy 2010, 8, 283-308. [CrossRef]

52. Yousef, D.A. Organizational Commitment, Job Satisfaction and Attitudes toward Organizational Change: A Study in the Local Government. Int. J. Public Adm. 2017, 40,77-88. [CrossRef]

53. Top, M.; Gider, O. Interaction of organizational commitment and job satisfaction of nurses and medical secretaries in Turkey. Int. J. Hum. Resour. Manag. 2013, 24, 667-683. [CrossRef]

54. Chordiya, R.; Sabharwal, M.; Goodman, D. Affective Organizational Commitment and Job Satisfaction: A Cross-National Comparative Study. Public Adm. 2017, 95, 178-195. [CrossRef]

55. Mathieu, J.E.; Zajac, D.M. A review and meta-analysis of the antecedents, correlates, and consequences of organizational commitment. Psychol. Bull. 1990, 108, 171-194. [CrossRef]

56. Sureshchandar, G.; Rajendran, C.; Anantharaman, R. A holistic model for total quality service. Int. J. Serv. Ind. Manag. 2001, 12, 378-412. [CrossRef]

57. Sungu, L.J.; Weng, Q.D.; Hu, E.; Kitule, J.A.; Fang, Q. How Does Organizational Commitment Relate to Job Performance? A Conservation of Resource Perspective. Hum. Perform. 2019, 33, 52-69. [CrossRef]

58. Ramayah, T.; Samat, N.; Lo, M. Market orientation, service quality and organizational performance in service organizations in Malaysia. Asia-Pac. J. Bus. Adm. 2011, 3, 8-27. [CrossRef]

59. Sayeda, B.; Rajendran, C.; Lokachari, P.S. An empirical study of total quality management in engineering educational institutions of India. Benchmarking Int. J. 2010, 17, 728-767. [CrossRef]

60. Dimitriades, Z.S. Customer satisfaction, loyalty and commitment in service organizations. Manag. Res. News 2006, 29, 782-800. [CrossRef]

61. Kanji, G.K.; Tambi, A.M.B.A.; Wallace, W. A comparative study of quality practices in higher education institutions in the US and Malaysia. Total Qual. Manag. 1999, 10, 357-371. [CrossRef]

62. Das, A.; Handfield, R.B.; Calantone, R.J.; Ghosh, S. A Contingent View of Quality Management-The Impact of International Competition on Quality. Decis. Sci. 2000, 31, 649-690. [CrossRef]

63. Jun, M.; Cai, S.; Shin, H. TQM practice in maquiladora: Antecedents of employee satisfaction and loyalty. J. Oper. Manag. 2005, 24, 791-812. [CrossRef]

64. Uppal, S. Disability, workplace characteristics and job satisfaction. Int. J. Manpow. 1985, 6, 1-50. [CrossRef]

65. Dow, D.; Samson, D.; Ford, S. Exploding the Myth: Do All Quality Management Practices Contribute to Superior Quality Performance? Prod. Oper. Manag. 2009, 8, 1-27. [CrossRef]

66. Powell, T.C. Total quality management as competitive advantage: A review and empirical study. Strat. Manag. J. 1995, 16, 15-37. [CrossRef]

67. Yee, R.W.; Yeung, A.C.; Cheng, T.E. The impact of employee satisfaction on quality and profitability in high-contact service industries. J. Oper. Manag. 2008, 26, 651-668. [CrossRef]

68. Kaplan, R.S.; Norton, D.P. The balanced scorecard-measures that drive performance. Harv. Bus. Rev. 1991, 70, 71-79.

69. Jabatan, P.P. Laporan Tahunan 2015; Jabatan Pendidikan Politeknik dan Kolej Komuniti: Putrajaya, Malaysia, 2015.

70. Anderson, J.C.; Gerbing, D.W. Structural equation modeling in practice: A review and recommended two-step approach. Psychol. Bull. 1988, 103, 411-423. [CrossRef]

71. Awang, Z.; Hui, L.S.; Zainudin, N.F.S. Pendekatan Mudah SEM-Structural Equation Modelling; MPWS Rich Resources: Bandar Baharu Bangi, Malaysia, 2015.

72. Mohamad, M.; Afthanorhan, A.; Awang, Z.; Mohammad, M. Comparison between CB-SEM and PLS-SEM: Testing and confirming the maqasid syariah quality of life measurement model. J. Soc. Sci. Res. 2019, 5, 608-614. [CrossRef]

73. Zaefarian, G.; Henneberg, S.C.; Naudé, P. Assessing the strategic fit between business strategies and business relationships in knowledge-intensive business services. Ind. Mark. Manag. 2013, 42, 260-272. [CrossRef]

74. Santos, G.; Marques, C.S.; Justino, E.; Mendes, L. Understanding social responsibility's influence on service quality and student satisfaction in higher education. J. Clean. Prod. 2020, 256, 120597. [CrossRef]

75. Priyadarshi, P. Employer Brand Image as Predictor of Employee Satisfaction, Affective Commitment \& Turnover. Indian J. Ind. Relat. 2011, 46, 510-522.

76. Dhir, S.; Shukla, A. Role of organizational image in employee engagement and performance. Benchmarking Int. J. 2019, 26, 971-989. [CrossRef]

77. Hull, C.E.; Lio, B.H. Innovation in non-profit and for-profit organizations: Visionary, strategic, and financial considerations. J. Chang. Manag. 2006, 6, 53-65. [CrossRef] 